\title{
Argument for The Reclassification of Yoruba as A Language Isolate
}

\author{
Seun Ayoade* \\ Department of Physiology, University of Ibadan, Nigeria
}

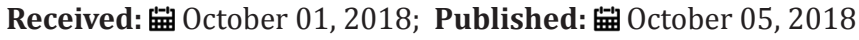

*Corresponding author: Seun Ayoade, BSc (Hons) Alumnus, College of Medicine U.I, Independent Researcher, Nigeria

\section{Mini Review}

Whereas the uniquely tonal language of Yoruba is currently classified as belonging to one of the 'families' of African languages an argument can be made that this is a misnomer, made by patronizing European explorers and linguists of the $19^{\text {th }}$ and early 20th centuries. The principal reason Yoruba came to be thus classified was because of similarities European racists found between Yoruba and some other Nigerian/west African languages. Assuming subSaharan Africans had no history and had never set up kingdoms and colonies of their own it simply never occurred to these prejudiced Europeans and Americans that these other languages that so resembled Yoruba had been at some time colonized by the Yoruba and had borrowed syntax and words from the Yoruba. Here I present evidence that all the languages classed into the family of languages Yoruba is now classed into were once victims of Yoruba colonization. Next, I present evidence that The Yoruba language is indeed a language isolate.

At present many sources class Yoruba as being in the Kwa subgroup of the 'Niger Congo Family' or in the 'west Sudanic family'. This family consists of such languages as Twi, Asante and Fanti (spoken in Ghana), Ibo and nupe (spoken in Nigeria) and Ewe, Fon and Togo (spoken in Benin republic) [1]. Evidence that the speakers of these non-Yoruba languages were victims of Yoruba colonization abound viz- "The Oyo Empire dominated during its apogee (16501750AD) most of the countries between the Volta River (Burkina Faso) in the west and Niger River (Nigeria) in the east" [2] "The Oyo Empire, established by The Yoruba people, controlled a wide area between the Volta (Burkina Faso) and Niger Rivers (Nigeria) by the mid-17 $7^{\text {th }}$ Century' [3]. According to the Encyclopaedia Britannica 1990 Edition: "Oyo subjugated the kingdom of Dahomey in the west in two phases (1724-1730, 1738-1748) [4].

The History of West Africa 1700-1800 states- "Much of the area of modern Dahomey (Benin Republic) seems to have come within the domain of the Yoruba Empire. Sango is said to have conquered the popo (perhaps as we have seen, in the $14^{\text {th }}$ or $15^{\text {th }}$ century). An
Alaafin of Oyo is said to have ruled in the area in the $16^{\text {th }}$ century. Thus by 1600 there was still considerable cultural contact between people in the Dahomey area and the Yoruba of both Oyo and Ife. The Yoruba language was understood and used right along the coast to the frontiers of modern Ghana. The kingdom of Allada, or Ardrah, which exercised authority over the Aja peoples of the coast, shared to a very large extent Yoruba civilization [5]- "An Empire of this type, with Oyo as its centre thus extended over most of western Nigeria, as far as the lower Niger in the east, to the west as far as far as Atakpame in Togo, while in the north it controlled Nupe and Borgu. [6] 'By 1400 The Yoruba were already organized in a complex system of city states. In the $18^{\text {th }}$ century Oyo exacted tribute from Dahomey, which it first invaded and devastated 1726-1730. [7]

Table 1: Morphing of non-Yoruba languages.

\begin{tabular}{|c|c|c|c|c|c|c|}
\hline Yoruba & Benin & Igala & Idoma & $\begin{array}{c}\text { West } \\
\text { Igbo }\end{array}$ & Ewe & Fon \\
\hline ogbe & ogbi & ebi & ebi & ogbi & gbe & gbe \\
\hline oyeku & ako & aku & akwu & akwu & yeku & Yeku \\
\hline iwori & oghoi & ogoli & ogoli & woli & oli & yeku \\
\hline odi & odi & oji & odi & odi & di & di \\
\hline iresun & oruhu & Oloru & olo & ulushu & loso & looso \\
\hline owara & oghae & egali & egali & ogai & noli & nwele \\
\hline obara & ovba & obata & obla & obai & abla & abala \\
\hline okanran & oka & okara & okla & okai & akla & akana \\
\hline ogunda & eghita & ejita & ejita & Ejita & guda & guda \\
\hline osa & oha & ora & ola & osha & sa & sa \\
\hline ika & eka & eka & eka & eka & ka & ka \\
\hline oturupon & erhowa & $\begin{array}{c}\text { Atunuk- } \\
\text { pa }\end{array}$ & $\begin{array}{c}\text { Etruk- } \\
\text { pa }\end{array}$ & atokpa & $\begin{array}{c}\text { truk- } \\
\text { pe }\end{array}$ & truk-pe \\
\hline otuwa & eture & otula & otre & etile & tula & tula \\
\hline irete & ete & ete & ete & ete & lete & ete \\
\hline ose & ose & oce & oce & ose & tse & che \\
\hline ofun & ohu & ofu & ofu & ofu & fu & fu \\
\hline
\end{tabular}


'The central area of Yoruba settlement was characterized by the presence of unusually large towns inhabited by agriculturists, craftsmen and traders. The subjects of the Alaafin must have outnumbered many times that of any other ruler.' [8] 'Oyo became the most powerful West African kingdom in the $17^{\text {th }}$ and $18^{\text {th }}$ century' [9]. Below we see a clear example of the 'morphing' of nonYoruba languages under Yoruba influence, precisely as it relates to Ifa -the Yoruba oracle [10]. In the Yoruba language every syllable corresponds to one of the first three notes of the tonic sol-fa/major scale i.e. doh-rah-me (d, r, m). It is impossible to utter a word in the Yoruba language without the word having syllables corresponding precisely to doh, ray or me. Hence the famous Yoruba 'talking drums' (gangan etc). What other language on planet earth has this characteristic? This tonic solfa feature of course results in several words having exactly the same spelling but entirely different sounds and meanings, viz-

$$
\begin{aligned}
& \text { i. Kolokolo }(\mathrm{m}, \mathrm{m}, \mathrm{m}, \mathrm{m})=\text { stealthily } \\
& \text { ii. Kolokolo (m, r, d, r) =circuitously } \\
& \text { iii. Kolokolo (d, d, m, m) =muddy, miry } \\
& \text { iv. Kolokolo (d, d, d, d) =fox [11] Also, } \\
& \text { v. Oko }(\mathrm{r}, \mathrm{r})=\text { husband, -with accent below both vowels } \\
& \text { vi. Oko }(\mathrm{r}, \mathrm{r})=\text { farm, } \text {-with no accent below either vowel } \\
& \text { vii. Oko }(\mathrm{r}, \mathrm{m})=\text { hoe, - with accent below both vowels } \\
& \text { viii. Oko }(\mathrm{r}, \mathrm{m}) \text { =penis, - with no accent below either vowel } \\
& \text { ix. Oko }(\mathrm{d}, \mathrm{d})=\text { spear } \\
& \text { x. Oko }(\mathrm{r}, \mathrm{d}) \text {-vehicle, -with accent below both vowels } \\
& \text { xi. Oko }(\mathrm{r}, \mathrm{d})=\text { stone, - no accent below either vowel }
\end{aligned}
$$

Words like these abound in Yoruba, too numerous to state here. What other language on planet earth has this characteristic? Apart from the doh reh mi feature the vowels 'e' and 'o' have accented and unaccented forms (as shown above). Imagine if the speakers of the 'click' languages of southern Africa had colonized the Zulu, Xhosa, Shona, Swana etc. -and these other languages had taken up some element of clicking. Imagine if Europeans had arrived in South Africa and didn't know of when Zulus etc. had been colonized by Khoisan or speakers of the click languages. They would have concluded that Zulu, Xhosa, Shona etc. were in the 'click family' instead of concluding that the click language was a language isolate.
This is exactly what happened in Nigeria with the musical/tonal Yoruba language. In conclusion I declare that Yoruba is a language isolate and its classification as a member of the 'Niger Congo' family etc. is a relic from the racist stereotypes of the $19^{\text {th }}$ and early $20^{\text {th }}$ centuries. The sooner this misnomer is rectified in textbooks and other media worldwide the better.

\section{Not All Bad}

Funnily enough, the Encyclopedia Britannica 1902 version showed unusual tolerance and objectivity for its time by hinting Yoruba was fundamentally different from the languages of the surrounding tribes- "Before the introduction of letters the Yoruba's are said to have employed knotted strings, like the Peruvian quipus, for recording events of historic interest. Their language, which has been reduced to writing and carefully studied by Crowther, Bouche, Bowen and other missionaries, is spoken with considerable uniformity throughout the whole of the Yoruba domain, and has even penetrated with the enterprising native traders as far east as Kano in the Haussa country beyond the Niger. The best-known dialectic varieties are those of Egba, Jebu Ondo, Ife, Llorin, and Oyo (Yoruba proper, called also Nago); but the discrepancies are slight, while the divergence from the conterminous linguistic groups (Ewe in the west, Ibo, Nupe, and others in the east) appears to be fundamental." [12].

\section{References}

1. Chambers Encyclopaedia (1970) international learning systems corporation limited London 1 pp. 144.

2. Encyclopaedia Britannica (1990) (Edn).

3. Funk and Wagnalis New Encyclopaedia Funk and Wagnalis Inc USA p. 39.

4. Encyclopaedia Britannica (1990) Micropedia University of Chicago 9 p. 36.

5. History of West Africa (1700-1800) Tuition House London, The rapid Results College Course No 168b1 p. 40-43.

6. History of West Africa (1000-1700) AD p. 78.

7. The Greenwood Encyclopedia of International Relations 4 pp. 1890.

8. John D Hagreaves (1963) Prelude to The Partition of West Africa.

9. Encyclopedia Americana (2001) 20 pp. 338.

10. Stephen Skinner (1980) From Terrestrial Geomancy, London.

11. Samuel Johnson (1921) History of The Yorubas. Obadiah Johnson (Eds.); History of The Yorubas From the Earliest Times To the Beginning of The British Protectorate published By George Routeledge \& Sons, London, CSS Nigeria.

12. Encyclopedia Britannica (1902) emphasis on the word 'fundamental' added. 


\section{(C) (P) This work is licensed under Creative}

To Submit Your Article Click Here: $\quad$ Submit Article

DOI: 10.32474/PRJFGS.2018.02.000142

\begin{tabular}{|c|c|}
\hline PRJFGS & $\begin{array}{l}\text { Peer Reviewed Journal of Forensic } \\
\text { \& Genetic Sciences }\end{array}$ \\
\hline & $\begin{array}{l}\text { Assets of Publishing with us } \\
\text { - Global archiving of articles } \\
\text { - Immediate, unrestricted online access } \\
\text { - } \quad \text { Rigorous Peer Review Process }\end{array}$ \\
\hline 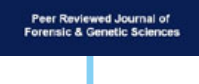 & $\begin{array}{l}\text { - Authors Retain Copyrights } \\
\text { - Unique DOI for all articles }\end{array}$ \\
\hline
\end{tabular}

